\title{
BIOLOGICAL ASPECTS OF THE IMMATURE STAGES OF Ceraeochrysa everes (BANKS) (NEUROPTERA: CHRYSOPIDAE)
}

\author{
Leonardo Rodrigues Barbosa $^{1 *}$; Sérgio de Freitas²; Alexander Machado Auad ${ }^{3}$ \\ ${ }^{1}$ Pós-Graduando em Agronomia/Entomologia - UFLA. \\ ${ }_{3}^{2}$ Depto. De Fitossanidade - UNESP/FCAV, Via de Acesso Paulo Donato Castellani, s/n- CEP: 14870-000 - Jaboticabal, SP. \\ ${ }^{3}$ Depto. de Entomologia - UFLA, C.P. 37 - CEP: 37200-000 - Lavras, MG. \\ *Autor correspondente <leonarbarbosa@bol.com.br>
}

\begin{abstract}
A knowledge of the behavior and biological aspects of natural enemies is extremely important for the establishment of biological control programs. Biological aspects of the larvae, pre-pupae and pupae of the predator Ceraeochrysa everes (Banks) were studied. Larvae of the adult $\mathrm{F}_{1}$ generation were reared in the laboratory $\left(25 \pm 2^{\circ} \mathrm{C}, 65 \pm 10 \% \mathrm{RH}\right.$ and $14 \mathrm{~h}$ photophase) on eggs of the Angoumois grain moth Sitotroga cerealella (Olivier). The duration and viability of the embryonic period, development of the immature stages and egg-adult period were evaluated. The mean embryonic period was 5.0 days, while the mean durations of the first, second and third instars were: $5.1 \pm 0.03 ; 4.3 \pm 0.05$ and $4.5 \pm 0.05$ days, respectively, with viability exceeding $90 \%$. Duration of the larval, pre-pupal and pupal stages averaged $13.9 \pm 0.07 ; 5.7 \pm 0.07$ and 9.6 \pm 0.12 days, respectively. Duration of the biological cycle was $34 \pm 0.11$ days on average. $S$. cerealella eggs were not suitable for rearing $C$. everes under laboratory conditions because they affected predator development. Key words: insecta, predator, biology, green lacewing
\end{abstract}

\section{ASPECTOS BIOLÓGICOS DOS ESTÁGIOS IMATUROS DE Ceraeochrysa everes (BANKS) (NEUROPTERA: CHRYSOPIDAE)}

\begin{abstract}
RESUMO: Para o estabelecimento de um programa de controle biológico, o conhecimento de alguns aspectos biológicos e de comportamento dos inimigos naturais é de extrema importância. Os aspectos biológicos do desenvolvimento larval e pupal do predador Ceraeochrysa everes (Banks) foram estudados. Larvas oriundas de adultos da geração $F_{1}$ foram mantidas em laboratório a $25 \pm 21^{\circ} \mathrm{C}, 70 \pm 10 \%$ UR e fotofase 14 horas, sendo alimentadas com ovos de Sitotroga cerealella (Olivier). A duração e viabilidade do período embrionário, estágios imaturos de desenvolvimento e o período de ovo a adulto foram avaliados. O período embrionário foi em média de 5,0 dias, enquanto que as durações médias para o primeiro, segundo e terceiro instares foram de $5,1 \pm 0,03 ; 4,3 \pm 0,05$ e 4,5 $\pm 0,05$ dias, respectivamente, com viabilidade superior a $90 \%$. Os estágios larval, pré-pupal e pupal apresentaram duração média de 13,9 $\pm 0,07 ; 5,7 \pm 0,07$ e 9,6 \pm 0,12 dias, respectivamente. A duração do ciclo biológico foi de $34 \pm 0,11$ dias em média. Ovos de $S$. cerelella não foram adequados para a manutenção de $C$. everes em laboratório, por interferir no desenvolvimento do predador. Palavras-chave: insecta, predador, crisopídeo, biologia
\end{abstract}

\section{INTRODUCTION}

The abusive use of agricultural pesticides has contributed to ecological degradation, contaminating the environment, promoting the development of insect pest resistance and the reduction of natural enemy populations, thus justifying the adoption of other pest control methods. In this context, the use of certain species of chrysopids as biological control agents has received considerable attention, because they are voracious predators and exhibit a high potential in reducing populations of many pest insects (Ridgway \& Jones, 1969; Scopes, 1969; Hagley, 1989; Gravena \& Cunha, 1991).

The duration of development and the survival of green lacewings are influenced by a number of factors, such as temperature, relative humidity, photoperiod, and food quality and quantity (Canard \& Principi, 1984). The influence of these factors was studied by Núñez (1988), for Ceraeochrysa cincta, and Silva et al. (1994) and Santa-Cecília et al. (1997) for Ceraeochrysa cubana.

Although the systematics and the biology of several groups have been intensely studied, the investigation of different species of Neuroptera, including some families that have not been adequately studied, should be considered (Stelzl \& Devetak, 1999). Considering that information on the biological aspects of lacewings is a pre-requisite for success when using these predators in biological control programs, the objective of this project was to study the larval and pupal developments of $C$. everes in laboratory conditions.

\section{MATERIAL AND METHODS}

The experiment was set in the Chrysopid Biosystematics and Mass Rearing Laboratory $\left(25 \pm 2^{\circ} \mathrm{C}\right.$; 
$65 \pm 10 \% \mathrm{RH} ; 14$-hour photophase), of the Plant Protection Department at "Faculdade de Ciências Agrárias e Veterinárias, UNESP Jaboticabal", using $F_{1}$ generation insects. The insects were identified by Dr. Sérgio de Freitas and the stock rearing was kept by using ten insect couples enclosed in a PVC tube cage $10 \mathrm{~cm}$ in diameter and $23 \mathrm{~cm}$ in height, lined with a sheet of white paper as substrate for oviposition. Adults were fed a yeast + honey (1:1) mixture, offered through a piece of plastic foam plugged to a $10 \mathrm{~mL}$ glass container. The eggs were collected daily and kept within plastic tubes $(5.5 \mathrm{~cm}$ in height and $8.0 \mathrm{~cm}$ in diameter) at a density of 10 eggs per container. The newlyhatched larvae were fed eggs of the lepidopteran Sitotroga cerealella (Olivier, 1819), which were glued to $6.3 ; 12.3$, and $18.8 \mathrm{~cm}^{2}$ pieces of poster board, and offered to first, second and third instar larvae, respectively. A total of 148 eggs were placed in glass vials $(2.5 \mathrm{~cm}$ diameter and $8.5 \mathrm{~cm}$ height), sealed with pin punctured PVC film. The larvae were fed with moth eggs these vials til adult emergence. The following parameters were recorded daily: embryonic period and egg viability, duration and viability of each larval instar, pre-pupal and pupal stages, and period from egg to adult. The period (days) was registered pre-pupal stage, from the beginning of cocoon spinning to the last larval exuvia, observed inside the cocoon.

\section{RESULTS AND DISCUSSION}

Mean duration of the embryonic period was 5 days (Table 1). Similar results were obtained by Moraes \& Carvalho (1991) and Silva et al. (1994) for C. cubana kept at $25^{\circ} \mathrm{C}$ and $\mathrm{RH} 70 \pm 10 \%$, and for $C$. cincta (Núñez, 1988), with an average of $6 \pm 2.1$ days when the eggs were placed at $25.3^{\circ} \mathrm{C}$, which indicates the occurrence of a slight variation of the embryonic period for different species of this genus. The average viability for this period was $80.4 \%$, lower than that $(97.7 \%)$ found for $C$. cubana by Silva et al. (1994), but close to the $79 \%$ related by Moraes \& Carvalho (1991).
When the larvae were fed eggs of $S$. cerealella the average duration of the first, second and third instars were: $5.1 \pm 0.03 ; 4.3 \pm 0.05$ and $4.5 \pm 0.05$ days, respectively (Table 1 ). Moraes (1989), studying C. cubana larvae fed $A$. kuehniella eggs plus Toxoptera sp. and maintained at $24^{\circ} \mathrm{C}$, measured an average first instar duration of 4.7 days, while Silva et al. (1994) verified an average duration of 4.0 days. Results for the second instar are similar to those found by Santa-Cecília et al. (1997) for C. cubana larvae fed A. kuehniella, and to those obtained by Núñez (1988) for $C$. cincta larvae fed $S$. cerealella. For the third instar, the average duration in $C$. everes was different from the duration found by Núñez (1988).

The mean duration for the larval stage was 13.9 $\pm 0,07$ days (Table 1 ). For $C$. cubana this value stage was 12.7 days (Santa-Cecília et al., 1997), and 15 days (Venzon \& Carvalho, 1993). These divergent values found for species of the genus Ceraeochrysa, should be due to differences in the environmental conditions under which the experiments were carried out, and to the capacity of each species to efficiently utilize a given type of prey. The viabilities for the instars and the larval period were higher than $90 \%$, thus showing that the diet and the temperature, humidity and photophase were fairly suitable for larval development.

The mean duration of the pre-pupal stage was $5.7 \pm 0.07$ days (Table 1 ). A lower value (one day) was obtained by Núñez (1988) for the pre-pupal stage in C. cincta. The mean viability for the pre-pupal stage in C. everes $(91.9 \%)$ was lower than that $(100 \%)$ observed by Venzon \& Carvalho (1993), for C. cubana maintained at $20 ; 25$; and $30^{\circ} \mathrm{C}$, regardless the diets tested.

In the pupal stage the mean duration was $9.6 \pm$ 0.12 days (Table 1 ). The $66.7 \%$ viability obtained for this stage was close to that found by Venzon \& Carvalho (1993) for C. cubana maintained at $20^{\circ} \mathrm{C}$. A higher viability was obtained by Santa-Cecília et al. (1997) when C. cubana larvae were fed $A$. kuehniella eggs and maintained at $25^{\circ} \mathrm{C}$.

Table 1 - Mean duration in days ( \pm SE), range (days) and viability of the different developmental stages of $C$. everes Temperature $25 \pm 2{ }^{\circ} \mathrm{C}, \mathrm{RH} 65 \pm 10 \%$ and $14 \mathrm{~h}$ photophase).

\begin{tabular}{|c|c|c|c|c|}
\hline Development & $\mathrm{n}$ & Duration & Range & Viability \\
\hline & & days & & ------ \% ------- \\
\hline Embryonic period. & 148 & $5.0 \pm 0.00$ & $(5-5)$ & 80.4 \\
\hline 1st instar & 119 & $5.1 \pm 0.03$ & $(5-7)$ & 93.3 \\
\hline 2 nd instar & 111 & $4.3 \pm 0.05$ & $(4-5)$ & 100 \\
\hline 3rd instar & 111 & $4.5 \pm 0.05$ & $(4-6)$ & 100 \\
\hline Larval stage & 111 & $13.9 \pm 0.07$ & $(13-19)$ & 93.3 \\
\hline Pre-pupal stage & 102 & $5.7 \pm 0.07$ & $(4-7)$ & 91.9 \\
\hline Pupa & 68 & $9.6 \pm 0.12$ & $(6-11)$ & 66.7 \\
\hline Period from egg to adult & 47 & $34.0 \pm 0.11$ & $(33-36)$ & 31.7 \\
\hline
\end{tabular}

$\mathrm{SE}=$ Standard error of the mean $\mathrm{n}=$ number of insects used 
The average duration of the period from egg to adult was $34 \pm 0.07$ days (Table 1 ). Similar results were found by Núñez (1988) for $C$. cincta maintained at $25.3^{\circ} \mathrm{C}$, and by Silva et al. (1994) for C. cubana in the $\mathrm{F} 2$ generation, at $25^{\circ} \mathrm{C}$. Although the $C$. evere larvae fed $S$. cerealella eggs showed high viability values for the different instars, there was malformation of pupae and consequently lower emergence of adults $(33 \%)$. This suggests the need to supplement this diet. Santa-Cecilia et al. (1997) verified that the percentage of adults of $C$. cubana emerging was 75 and $95 \%$ when the larvae were fed eggs of $A$. kuehniella only or supplemented with the Pinnaspis sp. (Hemiptera: Diaspididae) However, when this lacewing was fed Pinnaspis sp. only, the viability was $50 \%$, thus showing the importance of food during the larval stage upon the subsequent stages.

The avid consumption of some species of prey by green lacewings does not necessarily indicate that those prey species are nutritionally adequate. This was evidenced when eggs of $S$. cerealella, a highly accepted prey by the three instars of $C$. everes, induced high pupal mortality.

\section{CONCLUSION}

Considering the mass rearing of $C$. everes, $S$. cerealella eggs were not suitable for maintaining these insects in the laboratory, because they interfere with the predator development. The results demonstrate the need for food supplementation or even the use of other prey. However, C. everes possesses a potential that remains to be explored.

\section{REFERENCES}

CANARD, M.; PRINCIPI, M.M. Development of Chrysopidae. In: CANARD, M.; SEMÉRIA, Y.; NEW, T.R. (Ed.) Biology of Chrysopidae. The Hague: W. Junk, 1984. cap.4, p.57-75.
GRAVENA, S.; CUNHA, H.F. Predation of cotton leafworm first instar larvae, Alabama argillacea (Lepidoptera: Noctuidae). Entomophaga, v.36, p.481491, 1991.

HAGLEY, E.A.C. Release of Chrysoperla carnea Stephens (Neuroptera: Chrysopidae) for control of the green apple aphid, Aphis pomi De Geer (Homoptera: Aphididae). The Canadian Entomologist, v.121, p.309-315, 1989.

MORAES, J.C. Aspectos biológicos e seletividade de alguns acaricidas à Ceraeochrysa cubana (Hagen, 1861) (Neuroptera: Chrysopidae) em laboratório. Lavras, 1989. 85p. Tese (Mestrado) - Escola Superior de Agricultura de Lavras.

MORAES, J.C.; CARVALHO, C.F. Influência da fonte de carboidratos sobre a fecundidade e longevidade de Ceraeochrysa cubana (Hagen, 1861) (Neuroptera: Chrysopidae). Ciência e Prática, v.15, p.137-144, 1991.

NÚÑEZ, Z.E. Ciclo biológico y crianza de Chrysoperla externa y Ceraeochrysa cincta (Neuroptera: Chrysopidae). Revista Peruana de Entomologia, v.31, p.76-82, 1988.

RIDGWAY, R.L.; JONES, S.L. Inundative releases of Chrysopa carnea for control of Heliothis on cotton. Journal of Economic Entomology, v.62, p.177-180, 1969

SANTA-CECÍLIA, L.V.C.; SOUZA, B.; CARVALHO, C.F. Influência de diferentes dietas em fases imaturas de Ceraeochrysa cubana (Hagen) (Neuroptera: Chrysopidae). Anais da Sociedade Entomológica do Brasil, v.26, p.309-314, 1997.

SCOPES, N.E.A. The potential of Chrysopa carnea as a biological control agent of Myzus persicae on glasshouse chrysantemus. Annals of Applied Biology, v.64, p.433-439, 1969.

SILVA, R.L.X.; CARVALHO, C.F.; VENZON, M. Aspectos biológicos das fases imaturas de Ceraeochrysa cubana (Hagen, 1861) (Neuroptera, Chrysopidae), em quatro gerações sucessivas em laboratório. Ciência e Prática, v.18, p.13-17, 1994.

STELZL, M.; DEVETAK, D. Neuroptera in agricultural ecosystems. Agriculture, Ecosystems and Environment, v.74, p.305-321, 1999.

VENZON, M.; CARVALHO, C.F. Desenvolvimento larval, pré-pupal e pupal de Ceraeochrysa cubana (Hagen) (Neuroptera, Chrysopidae) em diferentes dietas e temperaturas. Anais da Sociedade Entomológica do Brasil, v.22, p.477-483, 1993.

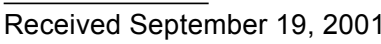

